\title{
Chemoproteomic Profiling by Cysteine Fluoroalkylation Reveals the DNA Repair Protein XRCC5 as a Functional Target of Myrocin G
}

\author{
Daniel Abegg, ${ }^{\dagger}$ Martin Tomanik, ${ }^{\ddagger}$ Nan Qiu, ${ }^{\dagger}$ Dany Pechalrieu, ${ }^{\dagger}$ Anton Shuster, ${ }^{\dagger}$ Bruno \\ Commare,,$^{\S}$ Antonio Togni, ${ }^{\S}$ Seth B. Herzon, ${ }^{\sharp \#}$ and Alexander Adibekian ${ }^{\dagger *}$ \\ † Department of Chemistry, The Scripps Research Institute, 130 Scripps Way, Jupiter, Florida 33458, United States \\ $\ddagger$ Department of Chemistry, Yale University, New Haven, Connecticut 06520, United States \\ $\S$ Department of Chemistry and Applied Biosciences, ETH Zürich, Vladimir-Prelog-Weg 2, CH-8093 Zürich, \\ Switzerland \\ \# Department of Pharmacology, Yale School of Medicine, New Haven, Connecticut 06520, United States
}

\begin{abstract}
Chemoproteomic profiling of cysteines has emerged as a powerful method for screening the proteomewide targets of cysteine-reactive fragments, drugs and natural products. Herein, we report the development and an indepth evaluation of a tetrafluoroalkyl benziodoxole as a cysteine-selective chemoproteomic probe. We show that this probe features numerous key improvements compared to the traditionally used cysteine-reactive probes, including a superior target occupancy, faster labeling kinetics, and broader proteomic coverage thus enabling profiling of cysteines directly in live cells. Further, the fluorine 'signature' of probe 7 constitutes an additional advantage resulting in a more confident adduct-amino acid site assignment in mass spectrometry-based identification workflows. We demonstrate the utility of our new probe for proteome-wide target profiling by identifying the cellular targets of (-)-myrocin $\mathrm{G}$, an antiproliferative fungal natural product with a to-date unknown mechanism of action. We show that this natural product and a simplified analog target the X-ray repair cross-complementing protein 5 (XRCC5), an ATP-dependent DNA helicase that primes DNA repair machinery for non-homologous end joining (NHEJ) upon DNA double strand breaks, making them the first reported inhibitors of this biomedically highly important protein. We further demonstrate that myrocins disrupt the interaction of XRCC5 with DNA leading to sensitization of cancer cells to the chemotherapeutic agent etoposide as well as UV-light induced DNA damage. Altogether, our next generation cysteine-reactive probe enables broader and deeper profiling of the cysteinome rendering it a highly effective tool for elucidation of targets of electrophilic small molecules.
\end{abstract}

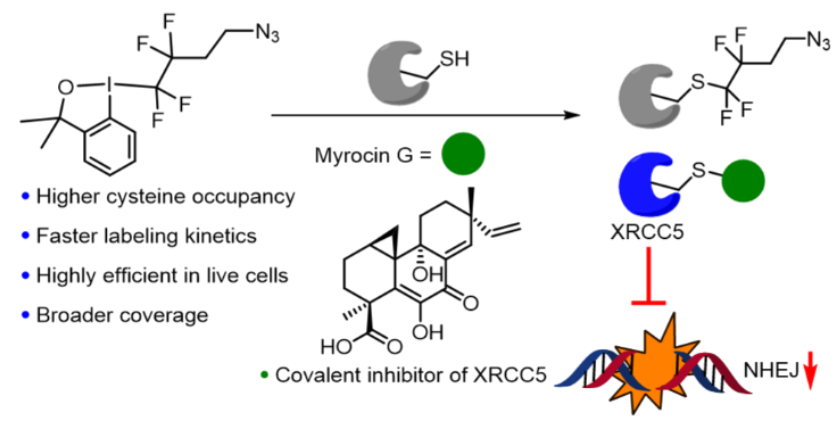




\section{Introduction}

Cysteines play an essential role in the structure and function of proteins due to their nucleophilicity and sensitivity to oxidation. ${ }^{1-3}$ The so-called functional cysteines can facilitate catalysis, coordinate metal ions, ${ }^{4-6}$ and undergo diverse post-translational modifications (PTMs). ${ }^{3,7-8}$ Functional cysteines tend to display pronounced hyperreactivity and these reactive cysteine hot spots can be precisely mapped in complex proteomes with cysteine-reactive electrophilic probes. These probes are particularly useful for competitive chemoproteomic profiling of cysteines as targets of natural products, ${ }^{9-14}$ libraries of covalent fragments, ${ }^{15-17}$ and electrophilic metabolites. ${ }^{18}$ Over the past decade, a broad variety of electrophilic probes for cysteine profiling have been reported. ${ }^{19-23}$ Despite the broad variety of reported cysteinereactive probes, only very few of them display sufficient reactivity, chemoselectivity, and bioorthogonality to find use in chemoproteomic applications. ${ }^{12,15-16,20,24-30}$ lodoacetamide (IAA) remains widely accepted in the proteomics field as gold standard among cysteine-reactive probes even though it only reacts with a relatively small subfraction of hyperreactive cysteines and displays only modest aqueous stability and low target occupancy. ${ }^{31}$ Target occupancy is a critical yet often overlooked probe parameter, which refers to the proportion of a certain probe-bound cysteine over the total number of this cysteine in the proteome and is largely dictated by the probe's chemical reactivity. In competitive profiling experiments, probes with high target occupancy allow 'deeper' profiling and identification of low occupancy binding events. Therefore, there is an unmet demand for new cysteine-reactive chemical probes that surpass existing probes with broader proteomic coverage, better performance in live cell experiments, and higher target occupancy to interrogate cysteine-related biology and facilitate discovery of cysteine-reactive inhibitors.

We recently reported the cysteine-reactive hypervalent iodine probe JW-RF-010, which reacted with a distinct share of proteomic cysteines compared to iodoacetamide alkyne. ${ }^{12}$ The total number of labeled cysteines, on the other hand, remained comparable to IAA alkyne meaning that a significant fraction of the cysteinome remained inaccessible to both probes. Inspired by the hypervalent iodine-based electrophilic fluoroalkylation chemistry, we herein present a new and vastly improved cysteine-reactive probe 7 which displays faster kinetics, broader coverage, and much higher target occupancy than IAA alkyne 1 and JW-RF-010 2 (Figures 1 and 2A). We show that 7 is exceptionally chemoselective for cysteines and, owing to its fast kinetics, can be used for profiling experiments directly in live cells. We demonstrate the utility of 7 as a chemoproteomic probe by identifying the cellular targets of (-)-myrocin $G$, an antiproliferative fungal natural product with a to-date unknown mechanism of action. ${ }^{32-33}$ We show that this natural product as well as its simplified analog (-)-11 target the key DNA repair protein X-ray repair cross-complementing protein 5 (XRCC5), an ATP-dependent DNA helicase that primes DNA repair machinery for non-homologous end joining (NHEJ) upon DNA double strand breaks. ${ }^{34-35}$ Our follow-up experiments show that both compounds undermine the DNA repair in HeLa cells by disrupting the binding of XRCC5 to DNA and chemosensitize the cells to etoposide- and UV-induced DNA damage.

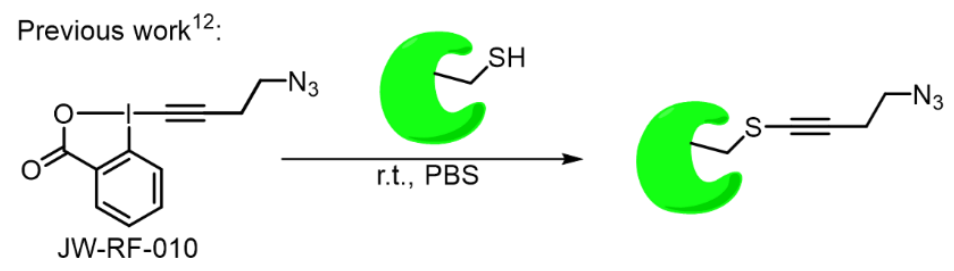

This work:

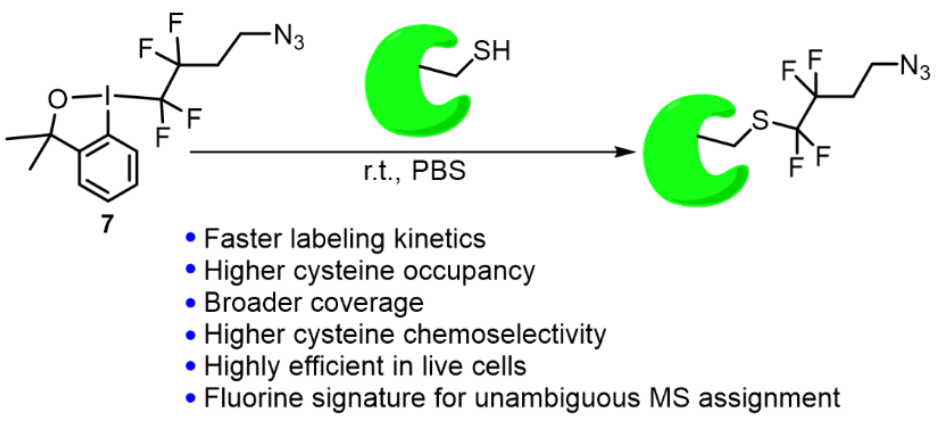

Figure 1. Chemical structures of our previous and new hypervalent iodine-based probes for chemoproteomic profiling of cysteines. 


\section{Results and Discussion}

Synthesis and evaluation of reactivity. Fluorine is absent in the native proteome and incorporation of fluorine atoms into proteomic probe structures increases the confidence in protein target and amino acid site assignment in mass spectrometry experiments. ${ }^{36-37}$ Such fluorine 'signatures' could in principle be introduced onto cysteine nucleophiles via electrophilic fluoroalkylation. 1-(Trifluoromethyl)-benziodoxoles are widely used as soft electrophilic trifluoromethylating reagents in organic synthesis. ${ }^{38-43}$ Beyond the traditional use as atom transfer reagents in organic synthesis, trifluoromethyl benziodoxoles have also been successfully used for trifluoromethylation of cysteines in peptides and single proteins. ${ }^{44-46}$ Intrigued by these earlier studies, we were curious to explore whether trifloromethyl benziodoxoles could also be used as selective chemoproteomic reagents for proteome-wide trifluoromethylation of cysteines under mild, physiological conditions (saline buffer, room temperature, short reaction times).

We initiated our studies by testing whether we are able to detect the fluoroalkyl-cysteine adducts in complex cellular lysates by mass spectrometry. HeLa cell lysates were treated with tris(2-carboxyethyl)phosphine (TCEP) to reduce the disulfides followed by treatment with $2 \mathrm{mM} \mathrm{1,3-dihydro-3,3-dimethyl-1-(trifluoromethyl)-1,2-benziodoxole} 3$ (Figure 2B). Proteins were then digested with trypsin and the peptides were analyzed by LC-MS/MS. Despite the high probe concentration, we were only able to detect a comparatively modest number of $1401 \mathrm{CF}_{3}$-cysteine adducts (Table S1). We repeated this experiment but now using the more electrophilic pentafluoroethyl-3,3-dimethyl benziodoxole $4 .{ }^{47-48}$ Indeed, the enhanced electrophilicity of the pentafluoroethyl substituent translated into broader cysteinome labeling leading to detection of 4169 modified cysteines (Table S2). To assess the cysteine reactivity and target occupancy of probe 4, we pretreated the HeLa lysates with $2 \mathrm{mM} 4$ or DMSO as control, followed by high concentration (50 mM) of the alkylating agent IAA. Pretreatment with $\mathbf{4}$ almost completely abolished broad carbamidomethylation of cysteines (IAA alkylation), indicating that the proteome-wide cysteine occupancy by 4 is high (Table S3).

Encouraged by these initial results, we continued our studies with the preparation of an azide-functionalized derivative of compound 4. Equipping 4 with a bioorthogonal handle would permit copper(I)-catalyzed alkyne-azide cycloaddition (CuAAC) for gel-based visualization or enrichment of probe modified peptides and proteins. The azide probe 7 was synthesized in three steps based on procedures reported for other tetrafluoroethylation reagents. ${ }^{45}$, 49 Briefly, commercially available 1,4-dibromo-1,1,2,2-tetrafluorobutane was reacted with sodium azide to yield the mono-azido bromide 5 . Trimethylsilylation of 5 was performed by in situ metalation using the Turbo-Grignard reagent (iPrMgCl. LiCl) and chlorotrimethylsilane to afford the corresponding azidofluoroalkylsilane $\mathbf{6}$. An umpolung reaction of 6 with fluoroiodane (1-fluoro-3,3-dimethyl-1,2-benziodoxole) yielded the final product 7 (Figure 2C).

The thiol reactivity of probes 1, 2, and 7 was evaluated using the reduced Ellman's reagent 2-nitro-5-thiobenzoic acid anion (TNB ${ }^{2-}$ ). TNB $^{2-}$ was incubated with $100 \mu \mathrm{M} \mathrm{1,2}$ or 7 resulting in time-dependent absorbance decrease at $412 \mathrm{~nm}$. Indeed, probe $7\left(k_{\mathrm{obs}}=27.1 \mathrm{M}^{-1} \mathrm{~s}^{-1}\right)$ showed 4.5 -fold higher reactivity with $\mathrm{TNB}^{2-}$ than our previously reported ethylbenziodoxolone probe $2\left(k_{\mathrm{obs}}=6.1 \mathrm{M}^{-1} \mathrm{~s}^{-1}\right)$ and 10 -fold higher reactivity than $1\left(k_{\mathrm{obs}}=2.8 \mathrm{M}^{-1} \mathrm{~s}^{-1}\right)($ Figure $2 \mathrm{D})$.

A

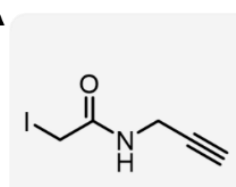

IAA alkyne

1

B

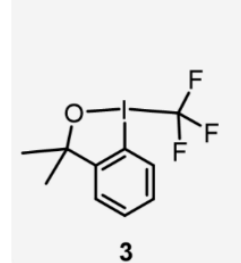

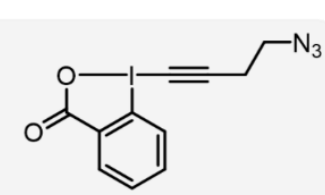

JW-RF-010

2

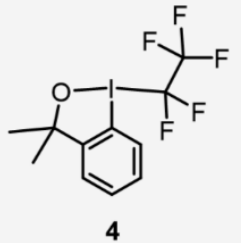

C<smiles>[R]C(F)(F)C(F)(F)CCBr</smiles><smiles>[R]C(F)(F)C(F)(F)CCNC1CC1CC1CC1</smiles>

(ii)<smiles>Br[R]B=[Bi]</smiles><smiles>C[SiH]=[Ru][Te]</smiles>

$\mathrm{D}$

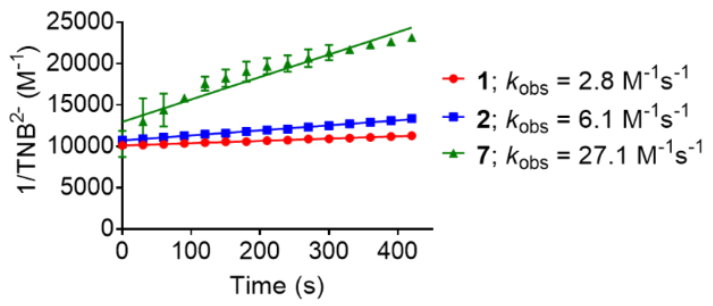

Figure 2. Synthesis and kinetic evaluation of probe 7. (A) Chemical structures of IAA alkyne (1) and JW-RF-010 (2). (B) Chemical structures of the 1,3-dihydro-3,3- dimethyl-1-(trifluoromethyl)-1,2-benziodoxole (3) and pentafluoroethyl-3,3-dimethyl benziodoxole (4). (C) Synthesis of probe 7. Reaction conditions: (i) $\mathrm{NaN}_{3}$ (3 eq) in DMF, $90{ }^{\circ} \mathrm{C}, 6$ hours; (ii) $\mathrm{Me}_{3} \mathrm{SiCl}\left(3.0\right.$ eq), $-78{ }^{\circ} \mathrm{C}$ followed by i$\mathrm{PrMgCl} \cdot \mathrm{LiCl}(1.3 \mathrm{eq})$ in THF, $-78^{\circ} \mathrm{C}$ to r.t., 12 hours; (iii) 1 -fluoro-3,3-dimethyl-1,2-benziodoxole $(2.0 \mathrm{eq})$, TBAT $(0.01 \mathrm{eq}),-35^{\circ} \mathrm{C}$ followed by 6 in MeCN, $-35^{\circ} \mathrm{C}$ to r.t., 3 hours. (D) Second rate order constants of probes 1,2 and 7 determined using the TNB ${ }^{2-}$ assay. 
Evaluation of 7 as a chemoproteomic probe. We next proceeded with evaluating the performance of probe 7 in chemoproteomic experiments. We treated HeLa lysates with $10 \mu \mathrm{M} \mathbf{1}, 2$ or 7, followed by conjugation to a photocleavable (PC) biotin alkyne or azide linker ${ }^{12}$ via CuAAC, streptavidin enrichment, trypsin digestion, UV release and LC-MS/MS analysis of probe-modified and enriched peptides. The MS data of all three probes was analyzed with Proteome Discoverer using the Sequest HT algorithm. ${ }^{50}$ In total, we found 2248 cysteines modified by 1 and 22352 modified cysteine sites. In comparison, the dataset from 7-treated proteome contained 3637 cysteines, which represents a $\sim 60 \%$ improvement compared to the two reference probes (Figure 3A and Tables S4-S6). Interestingly, a comparably large proportion of these cysteines, 1751 sites (48\% of the entire dataset), were uniquely identified with probe 7. Most notably, the average peak area of 7-modified and enriched peptides was two orders of magnitude higher than the average peak area of 1-modified peptides (Figure 3B).

We next assessed the proteome-wide chemoselectivity of $\mathbf{7}$ in comparison to $\mathbf{1}$ and $\mathbf{2}$. For this purpose, we searched for the expected probe adduct mass on all nucleophilic amino acids (Cys, Asp, Glu, His, Lys, Ser, Thr, and Tyr). Indeed, probe 7 also displayed the highest chemoselectivity among the three probes with $98.2 \%$ adducts detected on cysteines (Figure 3C). We also examined whether we can obtain broader cysteinome coverage by using $100 \mu \mathrm{M} 1$ or $\mathbf{7}$, a 10-fold higher probe concentration. This time we identified 7818 adducts with 1 whereas 7 modified 10062 cysteines, showing a 29\% improvement compared to 1 (Figure 3D and Tables S7 and S8). We speculate that this number could be further improved by solid-phase enhanced sample preparation ${ }^{51}$ and sample fractionation. ${ }^{15}$ It is worth mentioning that 7 retained excellent cysteine selectivity (96.5\%) even at this high concentration (Figure $3 \mathrm{C}$ ) and that the average area of 7-modified peptides remained $~ 2.5$-fold higher than the area of 1-modified peptides (Figure 3B). We further performed a functional bioinformatic analysis of the cysteines uniquely labeled by $100 \mu \mathrm{M} 7$ compared to 1. Interestingly, Gene Ontology analysis ${ }^{52-53}$ showed that these uniquely labeled cysteines are statistically enriched among the membrane proteins which are generally much less found in cysteine profiling studies (Figure 3E). We believe that one possible explanation for this improved membrane protein labeling could be the increased lipophilicity of 7 due to its polyfluoroalkyl chain.

We further wondered whether the high hydrophobicity of 7 may also result in better cellular membrane penetration and thus more efficient cysteine labeling in live cell experiments. HeLa cells were treated with $100 \mu \mathrm{M} 1,2$ or $\mathbf{7}$ for different amounts of time, washed, and lysed. Lysates were conjugated to tetramethylrhodamine (TAMRA) via CuAAC and analyzed by in-gel fluorescence scanning after SDS-PAGE separation. Indeed, probe 7 showed the fastest live cell labeling kinetics among the three tested probes (Figures 3F and S1), with the fluorescent bands appearing as short as one minute after cell treatment. Owing to our interest in pharmacological targeting of biomedically important nuclear proteins, ${ }^{11,13,54}$ we also compared the labeling of nuclear cysteines in live HeLa cells. To this end, live HeLa cells were again treated with $100 \mu \mathrm{M} \mathrm{1,2}$ or 7, cellular nuclei were isolated, and the labeling efficiency was analyzed as described above. As expected, probe 7 labeled the nuclear proteome $\sim 1.8$-fold stronger than the EBX probe 2 and fivefold stronger than 1 (Figures 3G, 3H and S2).

The ability to achieve high target occupancy at micromolar concentrations is an important parameter for chemoproteomic probes used in competitive profiling experiments. If the probe only binds to a small fraction of a given proteomic cysteine, the competitor molecule would need to pre-block a very high proportion of this same cysteine in order to render this competition event detectable. High target occupancy may allow identification of additional protein targets of a small molecule, thus providing a more accurate picture of its interactome. To evaluate the median cysteine occupancy of our probe, we treated HeLa lysates first with TCEP to reduce the disulfides, then with DMSO, $100 \mu \mathrm{M} 1$, 2 or 7, followed by alkylation of the unoccupied cysteines with $50 \mathrm{mM}$ IAA and trypsin digestion (Figure 3I and Table S9). LC-MS/MS analysis was performed by searching for carbamidomethylation (IAA modification adduct) of cysteines. To compare the cysteine occupancy of the three different probes, we calculated the probe/DMSO intensity ratios for each peptide and converted them to percentage occupancy. Excitingly, probe 7 showed by far the highest median cysteine occupancy (69\%), followed by 2 (27\%) and 1 (1\%, Figure 3J). In summary, probe 7 displays faster labeling kinetics, deeper proteome coverage, improved chemoselectivity and higher median cysteine occupancy then the reference probes 1 and 2 . 
A

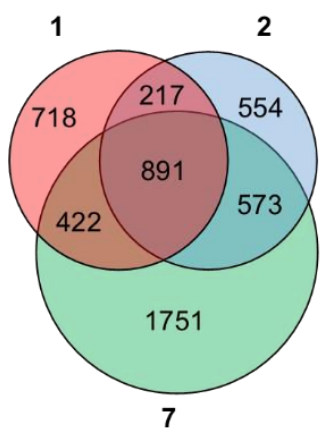

C

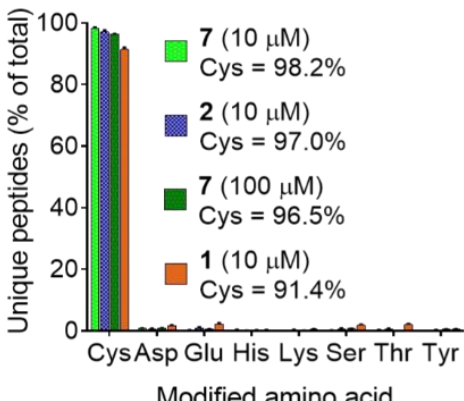

$\mathrm{D}$

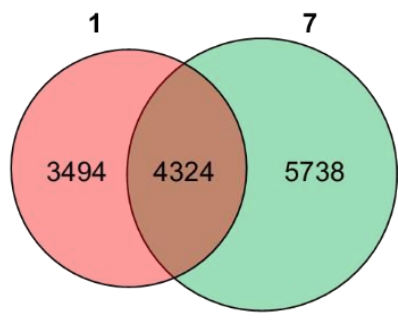

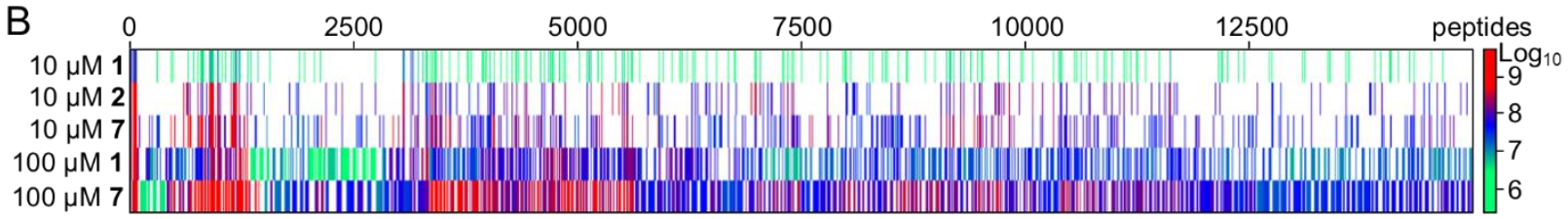

E

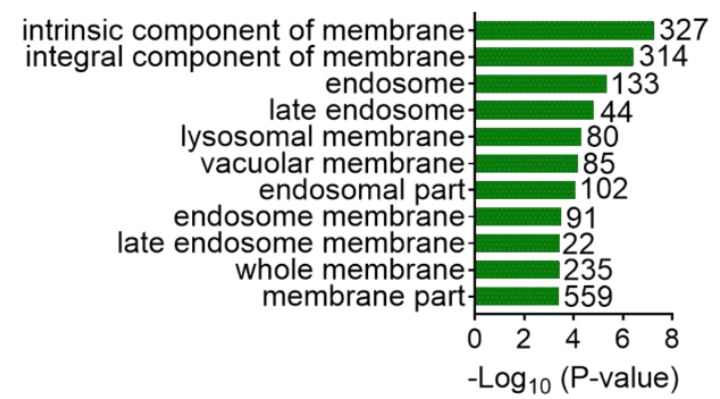

$\mathrm{F}$
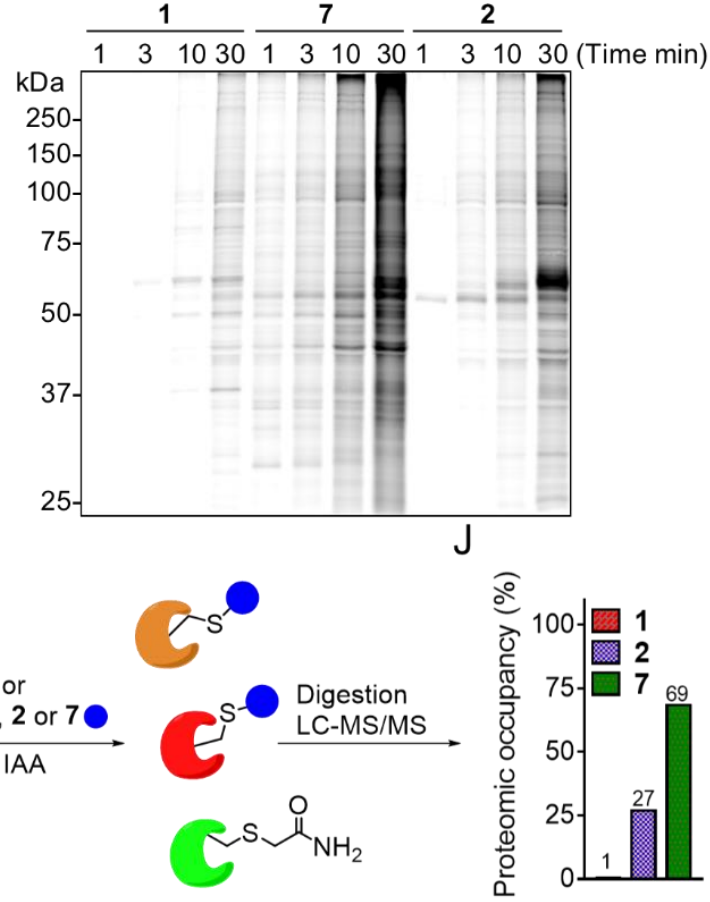

Figure 3. Evaluation of the proteome coverage, selectivity, and target occupancy of probe 7. (A) Venn diagram showing the distribution and overlap of cysteine-containing peptides modified with $10 \mu \mathrm{M} 1,2$ or 7. (B) Heatmap comparing the peak areas of 1, 2 or 7-modified peptides. Green shades indicate lower, blue medium, and red higher values, with white indicating that this particular peptide was not seen with the indicated probe. (C) LC-MS/MS-based amino acid chemoselectivity analysis of 1, 2, and 7 in HeLa lysates. (D) Venn diagram showing the overlap of $100 \mu \mathrm{M}$ 1- and 7-modified cysteine-containing peptides. (E) Gorilla GO terms analysis showing component-enriched terms of unqiue $100 \mu \mathrm{M}$ 7-labeled proteins compared to shared $100 \mu \mathrm{M} 1$ and $100 \mu \mathrm{M} 7$-labeled proteins. Number of proteins per GO term is shown. (F) Time-dependent labeling of live HeLa cells with different probes at $100 \mu \mathrm{M}$ concentration. (G) Gel-based analysis of the nuclear fraction labeling of HeLa cells following treatment with $100 \mu \mathrm{M}$ probe for 30 min. (H) Quantification of the total lane intensities of the gel shown in (G). (I) Workflow to determine the proteomic cysteine occupancy by different probes and $(\mathrm{J})$ quantification. Shown are the median ratios normalized to DMSO.

Identification of (-)-myrocin G cellular targets. To demonstrate the utility of $\mathbf{7}$ as chemoproteomic probe in target identification experiments, we sought to identify potential cellular targets of the natural product (-)-myrocin G 10. Myrocins are a family of fungal primarane diterpene antibiotics with antiproliferative and antitumor activities which were isolated from Myrothecium verrucaria. ${ }^{32,}{ }^{55}$ We focused on (-)-10 (Figure 4A), the putative active form of myrocin $C$ known as myrocin $\mathrm{G}$ that features two distinct electrophilic moieties: a strained cyclopropane and an $\alpha, \beta$-unsaturated 
ketone. As part of our program to identify novel etoposide synergizing agents, ${ }^{11,13}$ we observed that treatment with (-)10 in HeLa cells leads to chemosensitization of cancer cells to etoposide (Figure 4B), a clinically approved chemotherapeutic that induces DNA double-strand breaks. ${ }^{56}$ In this experiment, treatment with $30 \mu \mathrm{M}(-)-10$ alone did not cause any toxicity in HeLa cells after $24 \mathrm{~h}$, but significantly augmented the toxicity caused by etoposide addition. Preliminary chemical reactivity studies suggested that myrocins crosslink the DNA, but this hypothesis was not confirmed in our DNA plasmid cleavage and DNA crosslinking assays. ${ }^{55}$ We therefore wondered whether (-)-10 synergizes the etoposide activity through covalent engagement of an unknown cellular protein target. To test this hypothesis, we performed a target identification experiment using probes 1 and 7 and (-)-10 as competitor (Figure 4C). Briefly, HeLa cells were treated with $30 \mu \mathrm{M}(-)-10$ or DMSO for 4 hours followed by $100 \mu \mathrm{M}$ probe 1 or 7 for 30 minutes prior to lysis. The lysates were conjugated to desthiobiotin azide or alkyne ${ }^{57}$ via CuAAC. The samples were then digested, enriched by streptavidin, released and analyzed by LC-MS/MS.

Using 1 as enrichment probe, we were not able to identify any significantly competed protein targets (Figure 4D, left and Table S10). Using 7, however, we found 6 competed cysteines with a ratio $<0.2$ (Figure 4D right and Table S11). As an example for the importance of high target occupancy in competitive proteomic experiments, C97 of the ribosomal protein S3 (RPS3) was enriched with 1 and competed by (-)-10 with a ratio of 0.54 . With probe $\mathbf{7}$, however, we obtained a competition ratio of 0.16 clearly indicating that RPS3 C97 is a physical target of (-)-10. Excitingly, among the 6 identified targets, the nuclear protein X-ray repair cross-complementing protein 5 (XRCC5) stood out for its prominent role in repair of DNA double strand breaks caused by $y$ radiation and chemotherapeutic agents. ${ }^{58}$ In complex with XRCC6, XRCC5 forms the Ku-heterodimer that binds to fork-like DNA following a double strand break and orients the broken ends for subsequent recruitment of DNA-PKcs and NHEJ repair proteins (Figure 4E). ${ }^{59}$ Indeed, direct binding to XRCC5 may plausibly explain the etoposide chemosensitizing activity of (-)-10 which in this case may be caused by inhibition of DNA double-strand break repair.

A<smiles>C=C[C@@]1(C)C=C2C(=O)C(O)=C3[C@@](C)(C(=O)O)CCC4C[C@@]34[C@]2(C)CC1</smiles>

B

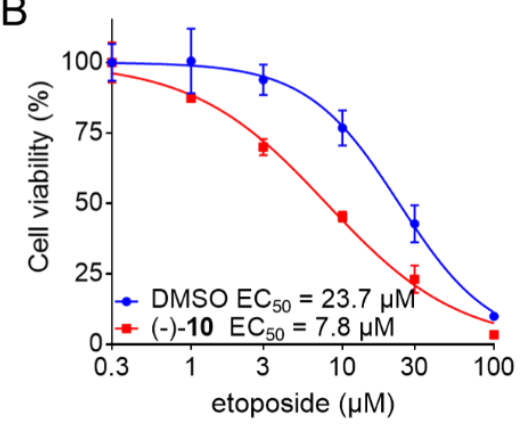

C

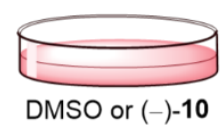

$$
\downarrow \begin{aligned}
& 7 \\
& \text { Lysis }
\end{aligned}
$$
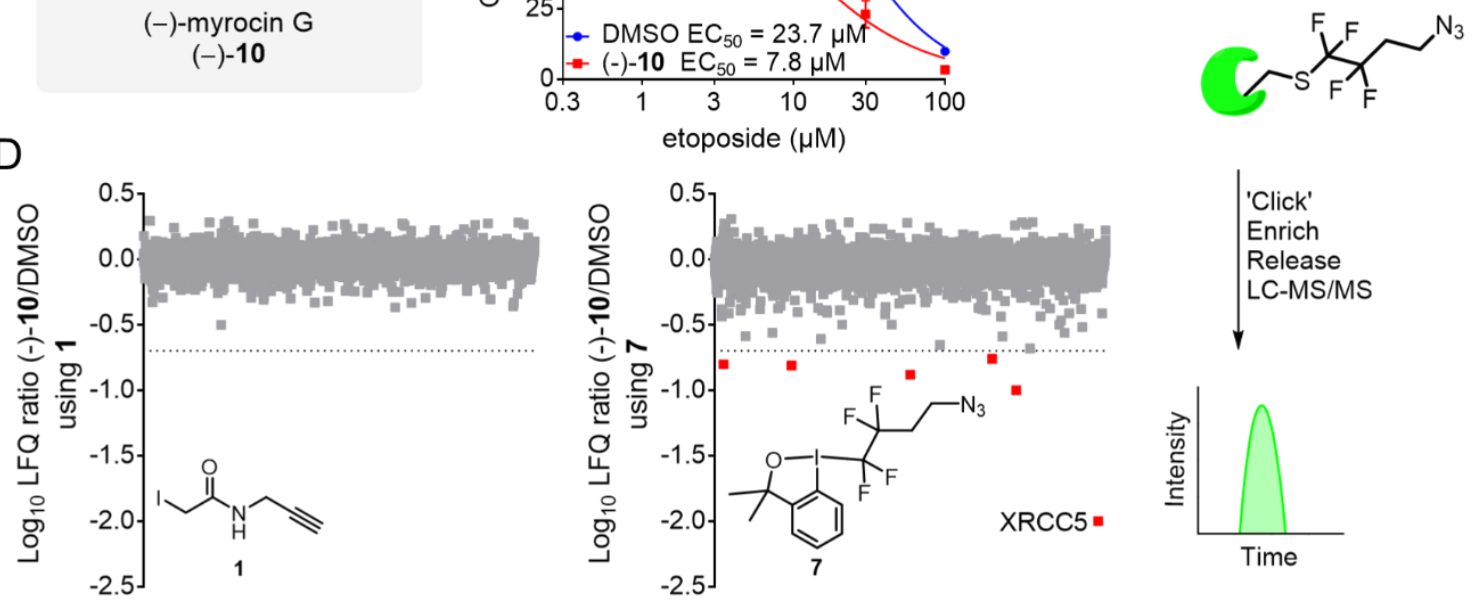

E
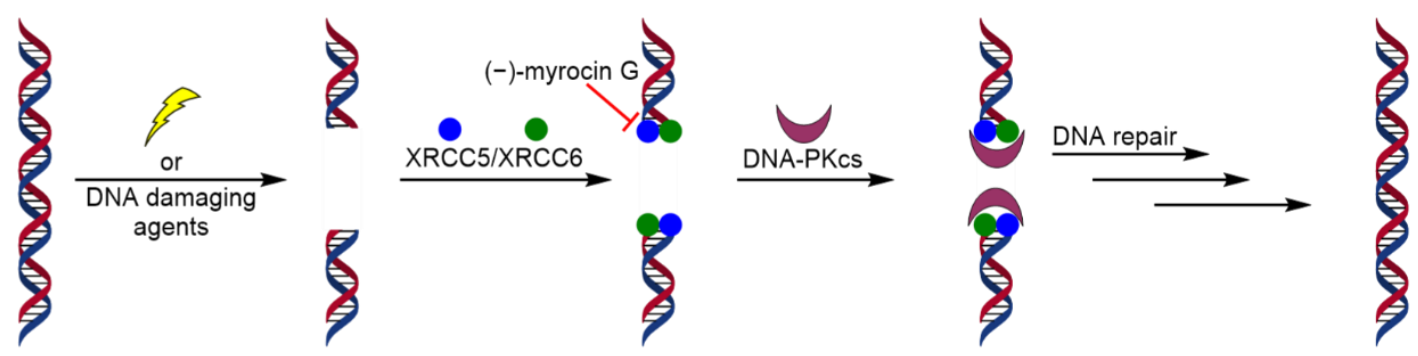

Figure 4. Identification of proteomic targets of (-)-myrocin G. (A) Chemical structure of (-)-myrocin G. (B) Cytotoxicity curves of HeLa cells co-treated with DMSO or $30 \mu \mathrm{M}(-)-10$ and etoposide for 24 hours. Shown are normalized values \pm SD $(n=3)$. (C) Workflow for 
a competitive target identification experiment using probe 7. (D) Scatter plot showing peptides enriched by $100 \mu \mathrm{M} 1$ (left) or $100 \mu \mathrm{M}$ 7 (right) with their respective competition ratios. HeLa cells were treated with $30 \mu \mathrm{M}(-)-10$ for 4 hours and target cysteines were identified using the workflow presented in (C). Shown are $\log _{10}$ ratios of $(-)-10$ over DMSO $(n=6)$. Competed peptides with ratios $<0.2$ are shown as red squares. The sequence of the competed XRCC5 peptide is HSIHWPC* R. (E) A schematic representation of the NHEJ DNA repair pathway and its inhibition by (-)-myrocin $\mathrm{G}$.

We also assessed the stereoselectivity of the (-)-10 interaction with its protein targets by profiling an enantiomeric pair of simplified analogs of (-)-10, methyl analogs (-)-11 and (-)-11 (Figure 5A), ${ }^{55}$ using probe 7 . Two cysteine targets, including the XRCC5 C249, were found to be shared between (-)-10 and (-)-11 but not with (+)-11 (Figure 5B and Table S12). Such stereoselective interactions with enantiomeric pairs indicate that the studied ligand-protein interaction is a product of authentic molecular recognition rather than high chemical reactivity of the ligand. ${ }^{60}$ Indeed, we confirmed that (-)-11 but not (+)-11 chemosensitize HeLa cells to etoposide treatment (Figure S3).

(-)-10 and (-)-11 interact with C249 in XRCC5 and disrupt DNA repair. Next, we proceeded to validate the binding of (-)-10 and (-)-11 to XRCC5 by pull-down and immunoblotting using (-)-12, an alkyne-derivatized probe of $(-)-11$ (Figure 5C). ${ }^{55}$ XRCC5-FLAG overexpressing lysates were pretreated with $30 \mu \mathrm{M}$ of $(-)-10,(-)-11$ or $(+)-11$, followed by $30 \mu \mathrm{M}(-)-12$, CuAAC click chemistry with biotin azide, and enrichment with streptavidin beads. The enriched proteins were then eluted from the beads and analyzed by Western blotting. As expected, (-)-10 and (-)-11, but not $(+)-11$, diminished the enrichment of XRCC5-FLAG by (-)-12 (Figure 5D). To validate C249 as the binding site, we overexpressed the wildtype (WT) and the C249S mutant XRCC5 proteins in HEK293T cells. As expected, (-)-12 enriched the WT XRCC5 but not the C249S mutant (Figure 5E). Finally, we determined the concentration of (-)-11 needed to achieve $50 \%$ fractional occupancy $\left(f_{\text {occ }}(50)\right)$ on endogenous XRCC5 to be $2.7 \mu \mathrm{M}$ (Figures $5 \mathrm{~F}$ and S4). Building on studies by Chu-Moyer and Danishefsky, ${ }^{61}$ we previously demonstrated that $(-)-10$ undergoes two-fold addition of benzenethiol with concomitant aromatization under mild conditions (14, Figure $5 \mathrm{G}$ ). ${ }^{55}$ The first step in this sequence involves 1,4-addition of benzenethiol followed by E1cb elimination of hydroxide, to form the monosulfide 13. Based on these data it seems plausible that (-)-10 binds to XRCC5 by a similar mode of addition (Figure $5 \mathrm{H})$. The fate of the 1,4-adduct $\mathbf{1 3}$ is not known at this time; additional reactions of the monosulfide with XRCC5 or exogenous nucleophiles cannot be excluded. 
A

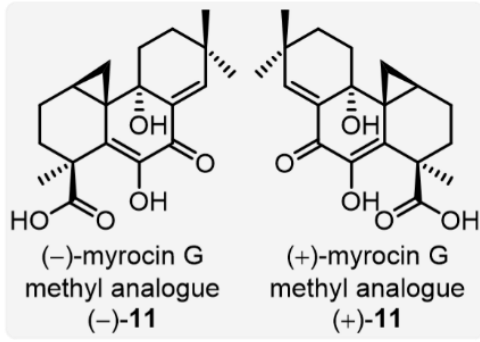

B

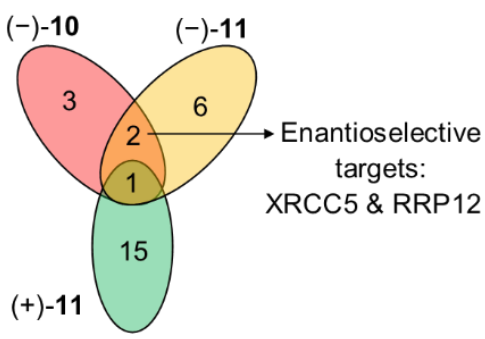

C

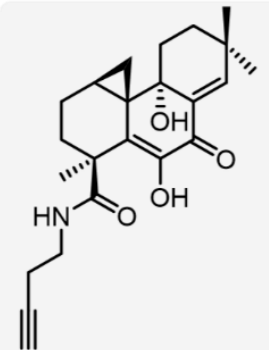

(-)-myrocin G methyl analogue alkynyl ester $(-)-12$

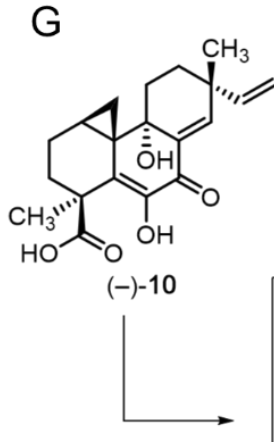

$\mathrm{H}$

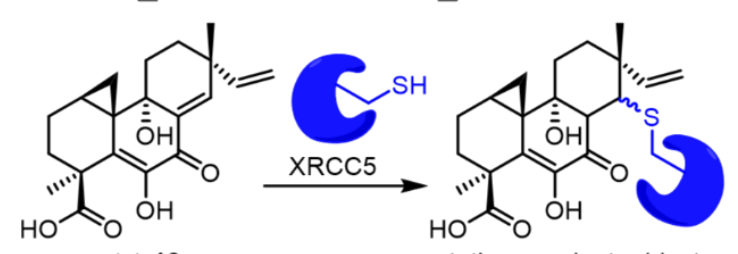

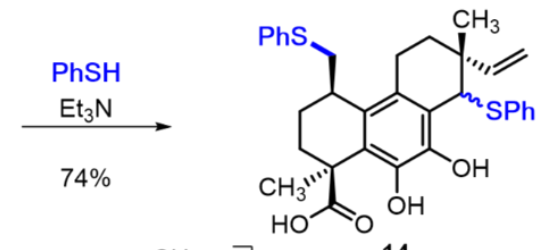

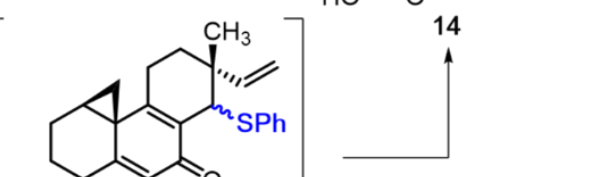

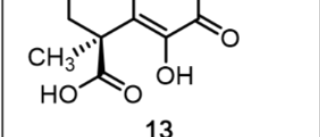

13 putative covalent adduct

$(-)-10$

E

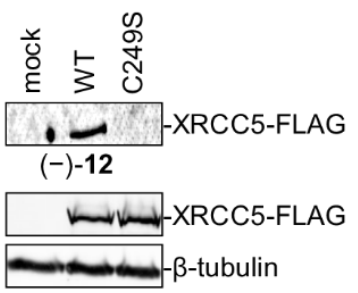

Input
F

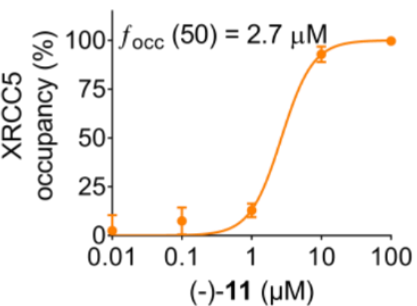

Figure 5. Validating XRCC5 C249 as a target of (-)-myrocin G and its analogs. (A) Chemical structures of (-)-myrocin G methyl analogs $(-)-11$ and $(+)-\mathbf{1 1}$. (B) Venn diagram showing the identified cysteine targets of $30 \mu \mathrm{M}(-)-\mathbf{1 0},(-)-\mathbf{1 1}$ and $(+)-\mathbf{1 1}$. HeLa cells were treated with DMSO or $30 \mu \mathrm{M}$ compound for 4 hours and samples were prepared as shown in Figure $4 \mathrm{C}$. (C) Chemical structure of probe (-)-12. (D) Pull-down experiment using $30 \mu \mathrm{M}$ probe (-)-12 from HEK293T lysates overexpressing XRCC5-FLAG and pretreated with DMSO, 10 and $30 \mu \mathrm{M}(-)-10,30 \mu \mathrm{M}(-)-11$ or $30 \mu \mathrm{M}(+)-11$ for 1 hour. CuAAC with biotin azide was performed, proteins were enriched via streptavidin agarose, released and Western blot membrane was probed for FLAG. Quantification is shown below. (E) Chemical pulldown of overexpressed XRCC5-FLAG WT or C249S from HEK293T lysates using 30 uM (-)-12. Probe treatment was followed by CuAAC with biotin azide, proteins were enriched via streptavidin agarose, eluted, separated by SDS-PAGE and probed by Western blotting. The agarose-eluted samples are shown on top and corresponding input controls on the bottom. (F) Fractional occupancy curve of the (-)-11 interaction with XRCC5. HeLa cells were treated with (-)-11 for 4 hours, lysed, XRCC5 was pulled down using $30 \mu \mathrm{M}(-)-\mathbf{1 2}$, released and quantified by Western blot. Shown are normalized values \pm SDs. (G) (-)-10 undergoes two-fold addition of benzenethiol, with concomitant aromatization, to form the bis(sulfide) 14. $(\mathrm{H})$ Postulated mode of alkylation of C249 in XRCC5 by (-)-10.

C249 is positioned on the edge of the DNA-binding $\beta$ barrel domain that fits in the profiles of major and minor grooves (Figure 6A). ${ }^{62}$ Based on the position of C249, we hypothesized that binding of (-)-10 and (-)-11 to XRCC5 C249 may impair its DNA repair activity by disrupting the interaction with DNA. To test this hypothesis, we performed an electrophoretic mobility shift (EMSA) assay (Figure 6B). Fluorescent oligonucleotides with blunt ends were incubated with purified XRCC5-FLAG in the presence or absence of $30 \mu \mathrm{M}(-)-11$ followed by native PAGE separation and in-gel fluorescence scanning. When purified XRCC5-FLAG was incubated with oligonucleotides, we observed a band shift indicating that XRCC5 binds the double stranded DNA (dsDNA). No dsDNA band shift was observed in the absence of protein. Pretreatment with $30 \mu \mathrm{M}(-)-11$ significantly reduced the formation of protein-DNA complex confirming that binding to C249 indeed impairs the DNA binding ability of XRCC5 (Figure 6B).

To further investigate the effect of myrocins on DNA repair, we imaged the formation of phosphorylated histone variant $\mathrm{H} 2 \mathrm{AX}$ S139 ( $\mathrm{\gamma H} 2 \mathrm{AX})$, an early marker of DNA damage, ${ }^{63-66}$ in HeLa cells. Treatment with the myrocins alone showed minimal $\mathrm{YH} 2 \mathrm{AX}$ signal comparable to the DMSO control (Figures $6 \mathrm{C}$ and S6). Treatment with $30 \mu \mathrm{M}$ etoposide alone led to a $\sim 4$-fold increase in $\mathrm{yH} 2 \mathrm{AX}$ signal, consistent with the mode of action of a topoisomerase II inhibitor (Figure 
6D). ${ }^{67}$ In combination with $30 \mu \mathrm{M}$ etoposide, however, (-)-10 and (-)-11 elicited significant chemosensitization showing a 2 -fold enhancement in $\mathrm{yH} 2 \mathrm{AX}$ intensity compared to etoposide alone. As expected, co-treatment with (+)-11 and etoposide did not enhance the DNA damage. Finally, genetic knockdown of XRCC5 also sensitized cells to etoposide while treatment of XRCC5 KD cells with myrocins did not lead to a further increase in $\mathrm{YH} 2 \mathrm{AX}$ intensity corroborating that the HeLa cell chemosensitization to etoposide occurred in an XRCC5-dependent manner (Figures 6C, 6D, S5 and S6). We also monitored DNA repair over time after UV exposure by quantifying $\mathrm{YH} 2 \mathrm{AX}$ signal at different time points post-irradiation. In the control experiment, DNA damage was resolved in 1 hour by the cells with a half-life of 27 minutes (Figures 6E and S7). When pre-sensitized with $30 \mu \mathrm{M}(-)-11$, however, a higher level of $\mathrm{yH} 2 \mathrm{AX}$ was detected following UV damage and the signal persisted until 4 hours post-irradiation. In the presence of (-)-11, DNA damage was resolved in much slower manner with a half-life of 106 minutes supporting our hypothesis that (-)-11 synergizes genotoxic insults by disrupting DNA repair. Altogether, these data showed that (-)-10 and (-)-11 sensitize cancer cells to etoposide and UV irradiation by impairing the DNA-repairing ability of XRCC5.

A

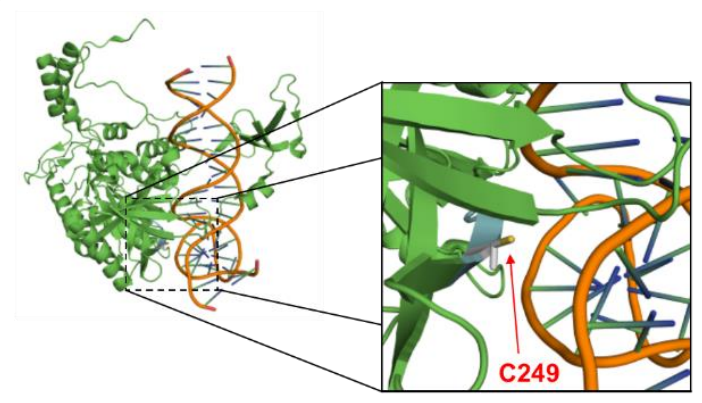

B

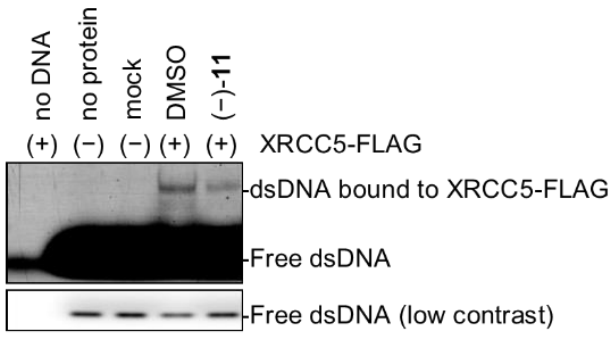

C

DMSO

etoposide

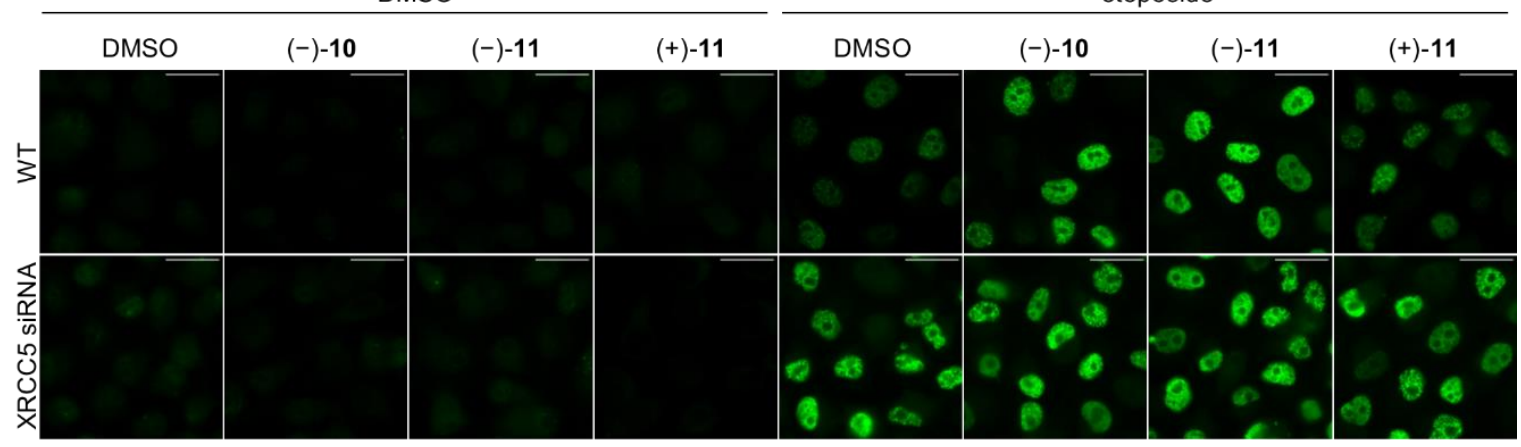

D

$\mathrm{E}$
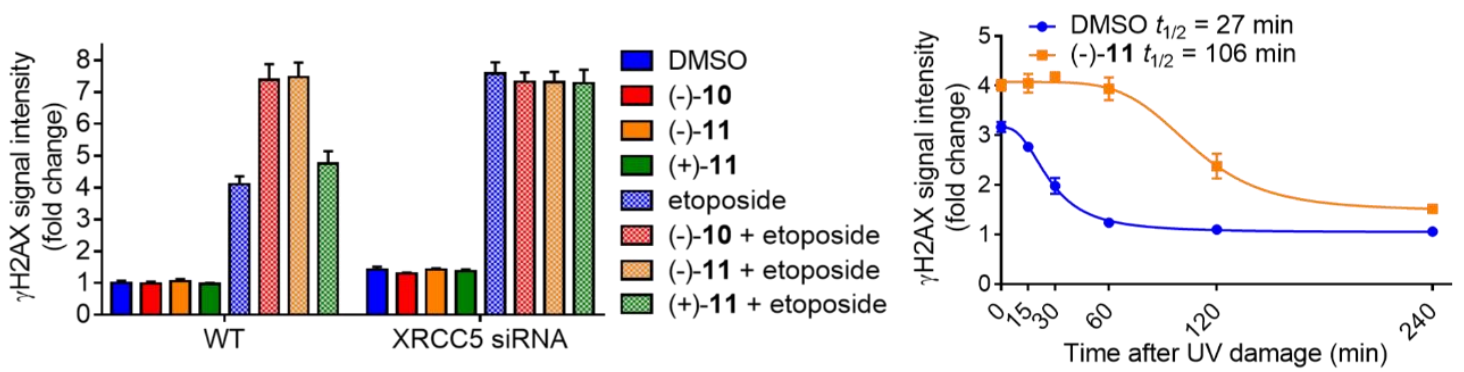

Figure 6. Binding of (-)-10 and (-)-11 to XRCC5 impairs DNA repair. (A) Crystal structure of XRCC5 (PDB: 1JEY) with the competed peptide shown in grey and C249 shown as sticks. (B) Fluorescent EMSA gel performed with purified XRCC5-FLAG with a 5' TAMRAlabeled 49 base long double stranded DNA (dsDNA). XRCC5-FLAG was treated with DMSO or $30 \mu \mathrm{M}(-)-11$ for 1 hour, incubated on ice for 30 min with 5' TAMRA dsDNA, separated by 5\% native PAGE and visualized by in-gel fluorescence. Shown are the high contrast (top) and low contrast (bottom) images. (C) Fluorescence microscopy images of yH2AX staining in mock or XRCC5 siRNAtreated HeLa cells upon co-incubation with $30 \mu \mathrm{M}(-)-10,(-)-11$ or $(+)-11$ and $30 \mu \mathrm{M}$ etoposide or DMSO for 6 hours and (D) quantification thereof. Shown values are fold changes to DMSO-treated mock \pm SEM. White bar indicates $30 \mu \mathrm{m}$. (E) Quantification of $\mathrm{yH} 2 \mathrm{AX}$ staining in HeLa cells pretreated with DMSO or $30 \mu \mathrm{M}(-)-\mathbf{1 1}$ for 1 hour, irradiated with $365 \mathrm{~nm}$ UV for 10 min and imaged at indicated time points. Shown values are fold change to non-irradiated, DMSO-treated cells \pm SEM. Fluorescence microscopy images are shown in Figure S7. 


\section{Conclusions}

In summary, we presented the development and an in-depth evaluation of a tetrafluoroalkyl benziodoxole as a cysteineselective chemoproteomic probe. We showed that the clickable benziodoxole probe 7 features broader proteomic coverage, faster kinetics, exquisite chemoselectivity even at higher probe concentrations, and a superior proteomewide target occupancy compared to iodoacetamide alkyne 1, which is currently considered the gold standard among cysteine-reactive chemoproteomic probes, and 2, our first generation hypervalent iodine-based proteomic probe. We further demonstrated that higher reactivity and faster kinetics of probe 7 translate into significantly faster engagement of cysteines in live cell experiments thus enabling cysteine profiling at much shorter time scale and directly in their native environment without cell lysis, buffer exchange, and disruption of the natively formed protein complexes. Further, the hydrophobic nature of our probe allows for improved profiling of membrane proteins whereas the fluorine 'signature' of probe 7 constitutes an additional advantage by allowing more confident target and amino acid site assignment in the subsequent mass spectrometry-based identification workflow. Thus, our next generation cysteine-reactive probe extends the detectable limits by probing 'broader' and 'deeper' into the cysteinome.

We demonstrated the usefulness of our clickable tetrafluoroalkyl benziodoxole 7 for target identification experiments by identifying XRCC5 as a cellular target of (-)-myrocin G 10 and its simplified analog (-)-11 amounting to the discovery of first small molecule ligands for this biomedically important DNA repair protein. In human cells, double-strand breaks (DSBs) are predominantly repaired by non-homologous end joining (NHEJ). ${ }^{68}$ Here the XRCC5/XRCC6 heterodimer recognizes the DSBs and recruits the DNA-dependent protein kinase catalytic subunit (DNA-PKcs) to initiate the repair. ${ }^{59}$ Increased expression levels of XRCC5 have long been associated with genotoxic anticancer treatment (chemo- and radiotherapy) resistance. ${ }^{69-75}$ For example, a recent study illustrated involvement of XRCC5 in temozolomide resistance in glioblastoma multiforme, one of the most common and fatal forms of brain cancer. ${ }^{76}$ XRCC5 has also been shown to drive tumor migration and invasion and is overexpressed in various cancers such as gastric cancer, breast cancer, and hepatocellular carcinoma. ${ }^{77-79}$ Herein, we showed that covalent engagement of XRCC5 cysteine 249 by myrocins (-)-10 and (-)-11 reduces its DNA binding ability and slows the DNA repair in cancer cells upon genotoxic insults such as etoposide treatment and UV irradiation. Several DNA repair inhibitors targeting the PARP enzymes have recently been clinically approved to combat various forms of cancer. ${ }^{80}$ We therefore believe that myrocins (-)-10 and (-)-11 represent an excellent starting point for the development of smaller, less complex, and more potent covalent XRCC5 inhibitors as anticancer agents with clinical potential. These studies are currently underway in our laboratories and the results will be reported in due course.

\section{ASSOCIATED CONTENT}

Experimental details. This material is available free of charge via the Internet at http://pubs.acs.org.

\section{AUTHOR INFORMATION}

\section{Corresponding Author}

aadibeki@scripps.edu

\section{ORCID}

Alexander Adibekian: 0000-0001-6453-0244

Daniel Abegg: 0000-0001-6829-3119

Antonio Togni: 0000-0003-3868-1799

Seth B. Herzon: 0000-0001-5940-9853

\section{Corresponding Authors}

The authors declare no competing financial interests.

\section{Present Address}

Martin Tomanik. Department of Chemistry, The Scripps Research Institute, 10550 N Torrey Pines Rd, California 92037, United States

Bruno Commare. Oril Industrie, 13 Rue Auguste Desgenetais, 76210 Bolbec, France

\section{Notes}

The authors declare no competing financial interests. 


\section{ACKNOWLEDGMENT}

This work was supported by the Reba \& Nat Newman fellowship, the NSF Graduate Research Fellowship, ETH Zürich, the National Institutes of Health (R35GM131913), Yale University, and the Scripps Research Institute.

\section{REFERENCES}

1. Weerapana, E.; Wang, C.; Simon, G. M.; Richter, F.; Khare, S.; Dillon, M. B. D.; Bachovchin, D. A.; Mowen, K.; Baker, D.; Cravatt, B. F., Quantitative reactivity profiling predicts functional cysteines in proteomes. Nature 2010, 468 (7325), $790-$ U79.

2. Marino, S. M.; Gladyshev, V. N., Cysteine Function Governs Its Conservation and Degeneration and Restricts Its Utilization on Protein Surfaces. J Mol Biol 2010, 404 (5), 902-916.

3. Reddie, K. G.; Carroll, K. S., Expanding the functional diversity of proteins through cysteine oxidation. Curr Opin Chem Biol 2008, 12 (6), 746-754.

4. $\quad$ Berg, J. M., Zinc Finger Domains - Hypotheses and Current Knowledge. Annu Rev Biophys Bio 1990, 19, 405-421.

5. Han, J.; Adman, E. T.; Beppu, T.; Codd, R.; Freeman, H. C.; Huq, L.; Loehr, T. M.; Sandersloehr, J., Resonance RamanSpectra of Plastocyanin and Pseudoazurin - Evidence for Conserved Cysteine Ligand Conformations in Cupredoxins (Blue Copper Proteins). Biochemistry-Us 1991, 30 (45), 10904-10913.

6. $\quad$ Werck-Reichhart, D.; Feyereisen, R., Cytochromes P450: a success story. Genome Biol 2000, 1 (6), REVIEWS3003.

7. Stamler, J. S.; Simon, D. I.; Osborne, J. A.; Mullins, M. E.; Jaraki, O.; Michel, T.; Singel, D. J.; Loscalzo, J., S-Nitrosylation of Proteins with Nitric-Oxide - Synthesis and Characterization of Biologically-Active Compounds. P Natl Acad Sci USA 1992, 89 (1), 444-448.

8. $\quad$ Aicart-Ramos, C.; Valero, R. A.; Rodriguez-Crespo, I., Protein palmitoylation and subcellular trafficking. Bba-Biomembranes 2011, 1808 (12), 2981-2994.

9. $\quad$ Gehrtz, P.; London, N., Electrophilic Natural Products as Drug Discovery Tools. Trends Pharmacol Sci 2021, 42 (6), 434-

447.

10. Isobe, Y.; Okumura, M.; McGregor, L. M.; Brittain, S. M.; Jones, M. D.; Liang, X. Y.; White, R.; Forrester, W.; McKenna, J. M.; Tallarico, J. A.; Schirle, M.; Maimone, T. J.; Nomura, D. K., Manumycin polyketides act as molecular glues between UBR7 and P53. Nat Chem Biol 2020.

11. Davis, D. C.; Hoch, D. G.; Wu, L.; Abegg, D.; Martin, B. S.; Zhang, Z. Y.; Adibekian, A.; Dai, M. J., Total Synthesis, Biological Evaluation, and Target Identification of Rare Abies Sesquiterpenoids. J Am Chem Soc 2018, 140 (50), 17465-17473.

12. Abegg, D.; Frei, R.; Cerato, L.; Prasad Hari, D.; Wang, C.; Waser, J.; Adibekian, A., Proteome-Wide Profiling of Targets of Cysteine reactive Small Molecules by Using Ethynyl Benziodoxolone Reagents. Angew Chem Int Ed Engl 2015, 54 (37), $10852-7$.

13. Cui, C.; Dwyer, B. G.; Liu, C.; Abegg, D.; Cai, Z. J.; Hoch, D. G.; Yin, X.; Qiu, N.; Liu, J. Q.; Adibekian, A.; Dai, M., Total Synthesis and Target Identification of the Curcusone Diterpenes. J Am Chem Soc 2021, 143 (11), 4379-4386.

14. Hoch, D. G.; Abegg, D.; Hannich, J. T.; Pechalrieu, D.; Shuster, A.; Dwyer, B. G.; Wang, C.; Zhang, X. J.; You, Q. D.; Riezman, H.; Adibekian, A., Combined Omics Approach Identifies Gambogic Acid and Related Xanthones as Covalent Inhibitors of the Serine Palmitoyltransferase Complex. Cell Chem Biol 2020, 27 (5), 586-+.

15. Kuljanin, M.; Mitchell, D. C.; Schweppe, D. K.; Gikandi, A. S.; Nusinow, D. P.; Bulloch, N. J.; Vinogradova, E. V.; Wilson, D. L.; Kool, E. T.; Mancias, J. D.; Cravatt, B. F.; Gygi, S. P., Reimagining high-throughput profiling of reactive cysteines for cell-based screening of large electrophile libraries. Nat Biotechnol 2021, 39 (5), 630-+.

16. Backus, K. M.; Correia, B. E.; Lum, K. M.; Forli, S.; Horning, B. D.; Gonzalez-Paez, G. E.; Chatterjee, S.; Lanning, B. R.; Teijaro, J. R.; Olson, A. J.; Wolan, D. W.; Cravatt, B. F., Proteome-wide covalent ligand discovery in native biological systems. Nature 2016, 534 (7608), 570-+.

17. $\quad$ Resnick, E.; Bradley, A.; Gan, J. R.; Douangamath, A.; Krojer, T.; Sethi, R.; Geurink, P. P.; Aimon, A.; Amitai, G.; Bellini, D.; Bennett, J.; Fairhead, M.; Fedorov, O.; Gabizon, R.; Gan, J.; Gu, J. X.; Plotnikov, A.; Reznik, N.; Ruda, G. F.; Diaz-Saez, L.; Straub, V. M.; Szommer, T.; Velupillai, S.; Zaidman, D.; Zhang, Y. L.; Coker, A. R.; Dowson, C. G.; Barr, H. M.; Wang, C.; Huber, K. V. M.; Brennan, P. E.; Ovaa, H.; von Delft, F.; London, N., Rapid Covalent-Probe Discovery by Electrophile-Fragment Screening. J Am Chem Soc 2019, 141 (22), 8951-8968.

18. Wang, C.; Cravatt, B. F., A Chemoproteomic Platform To Quantitatively Map Targets Of Lipid-Derived Electrophiles. Protein Sci 2014, 23, 191-191.

19. Hoch, D. G.; Abegg, D.; Adibekian, A., Cysteine-reactive probes and their use in chemical proteomics. Chem Commun 2018, 54 (36), 4501-4512.

20. Motiwala, H. F.; Kuo, Y. H.; Stinger, B. L.; Palfey, B. A.; Martin, B. R., Tunable Heteroaromatic Sulfones Enhance in-Cell Cysteine Profiling. J Am Chem Soc 2020, 142 (4), 1801-1810.

21. Patrick R. A., Z.; Fengchao, Y.; Patricia, M.; Lisa, L.; Michael, Z.; Kristina, K.; Dario, M.; Patrick, R.; Thomas E., M.; Marko, C.; Christopher, C.; Kathrin, L.; F. Dean, T.; Alexey I., N.; Stephan M., H., Profiling the Proteome-Wide Selectivity of Diverse Electrophiles. Chemrxiv: 2021.

22. Maurais, A. J.; Weerapana, E., Reactive-cysteine profiling for drug discovery. Curr Opin Chem Bio/ 2019, 50, 29-36.

23. Backus, K. M., Applications of Reactive Cysteine Profiling. Curr Top Microbiol Immunol 2019, 420, 375-417.

24. Banerjee, R.; Pace, N. J.; Brown, D. R.; Weerapana, E., 1,3,5-Triazine as a Modular Scaffold for Covalent Inhibitors with Streamlined Target Identification. J Am Chem Soc 2013, 135 (7), 2497-2500.

25. Abo, M.; Bak, D. W.; Weerapana, E., Optimization of Caged Electrophiles for Improved Monitoring of Cysteine Reactivity in Living Cells. Chembiochem 2017, 18 (1), 81-84.

26. $\quad$ Tessier, R.; Nandi, R. K.; Dwyer, B. G.; Abegg, D.; Sornay, C.; Ceballos, J.; Erb, S.; Cianferani, S.; Wagner, A.; Chaubet, G.; Adibekian, A.; Waser, J., Ethynylation of Cysteine Residues: From Peptides to Proteins in Vitro and in Living Cells. Angew Chem Int Edit 2020, 59 (27), 10961-10970.

27. Wang, C.; Abegg, D.; Hoch, D. G.; Adibekian, A., Chemoproteomics-Enabled Discovery of a Potent and Selective Inhibitor of the DNA Repair Protein MGMT. Angew Chem Int Ed Engl 2016, 55 (8), 2911-5. 
28. Bateman, L. A.; Nguyen, T. B.; Roberts, A. M.; Miyamoto, D. K.; Ku, W. M.; Huffman, T. R.; Petri, Y.; Heslin, M. J.; Contreras, C. M.; Skibola, C. F.; Olzmann, J. A.; Nomura, D. K., Chemoproteomics-enabled covalent ligand screen reveals a cysteine hotspot in reticulon 4 that impairs ER morphology and cancer pathogenicity. Chem Commun 2017, 53 (53), 7234-7237.

29. Roberts, A. M.; Miyamoto, D. K.; Huffman, T. R.; Bateman, L. A.; Ives, A. N.; Akopian, D.; Heslin, M. J.; Contreras, C. M.; Rape, M.; Skibola, C. F.; Nomura, D. K., Chemoproteomic Screening of Covalent Ligands Reveals UBA5 As a Novel Pancreatic Cancer Target. Acs Chem Biol 2017, 12 (4), 899-904.

30. Blewett, M. M.; Xie, J.; Zaro, B. W.; Backus, K. M.; Altman, A.; Teijaro, J. R.; Cravatt, B. F., Chemical proteomic map of dimethyl fumarate-sensitive cysteines in primary human T cells. Sci Signal 2016, 9 (445), rs 10.

31. Wong, H. L.; Liebler, D. C., Mitochondrial protein targets of thiol-reactive electrophiles. Chem Res Toxicol 2008, 21 (4), 796-

804.

32. Economou, C.; Tomanik, M.; Herzon, S. B., Synthesis of Myrocin G, the Putative Active Form of the Myrocin Antitumor Antibiotics. J Am Chem Soc 2018, 140 (47), 16058-16061.

33. Nakagawa, M.; Hsu, Y. H.; Hirota, A.; Shima, S.; Nakayama, M., Myrocin-C, a New Diterpene Antitumor Antibiotic from Myrothecium-Verrucaria .1. Taxonomy of the Producing Strain, Fermentation, Isolation and Biological Properties. J Antibiot 1989,42 (2), 218-222.

34. Taccioli, G. E.; Gottlieb, T. M.; Blunt, T.; Priestley, A.; Demengeot, J.; Mizuta, R.; Lehmann, A. R.; Alt, F. W.; Jackson, S. P.; Jeggo, P. A., Ku80 - Product of the Xrcc5 Gene and Its Role in DNA-Repair and V(D)J Recombination. Science 1994, 265 (5177), $1442-1445$.

35. Rivera-Calzada, A.; Spagnolo, L.; Pearl, L. H.; Llorca, O., Structural model of full-length human Ku70-Ku80 heterodimer and its recognition of DNA and DNA-PKcs. Embo Rep 2007, 8 (1), 56-62.

36. $\quad$ Cheng, M.; Zhang, B.; Cui, W.; Gross, M. L., Laser-Initiated Radical Trifluoromethylation of Peptides and Proteins: Application to Mass-Spectrometry-Based Protein Footprinting. Angew Chem Int Ed Eng/ 2017, 56 (45), 14007-14010.

37. Cheng, M.; Guo, C.; Gross, M. L., The Application of Fluorine-Containing Reagents in Structural Proteomics. Angew Chem Int Ed Engl 2020, 59 (15), 5880-5889.

38. Eisenberger, P.; Gischig, S.; Togni, A., Novel 10-I-3 hypervalent iodine-based compounds for electrophilic trifluoromethylation. Chemistry 2006, 12 (9), 2579-86.

39. Allen, A. E.; Macmillan, D. W., The productive merger of iodonium salts and organocatalysis: a non-photolytic approach to the enantioselective alpha-trifluoromethylation of aldehydes. J Am Chem Soc 2010, 132 (14), 4986-7.

40. Shimizu, R.; Egami, H.; Nagi, T.; Chae, J.; Hamashima, Y.; Sodeoka, M., Direct C2-trifluoromethylation of indole derivatives catalyzed by copper acetate. Tetrahedron Lett 2010, 51 (45), 5947-5949.

41. Parsons, A. T.; Senecal, T. D.; Buchwald, S. L., Iron(II)-Catalyzed Trifluoromethylation of Potassium Vinyltrifluoroborates. Angew Chem Int Edit 2012, 51 (12), 2947-2950.

42. Charpentier, J.; Fruh, N.; Togni, A., Electrophilic Trifluoromethylation by Use of Hypervalent lodine Reagents. Chem Rev 2015, $115(2), 650-682$.

43. Barata-Vallejo, S.; Lantano, B.; Postigo, A., Recent Advances in Trifluoromethylation Reactions with Electrophilic Trifluoromethylating Reagents. Chem-Eur J 2014, 20 (51), 16806-16829.

44. $\quad$ Capone, S.; Kieltsch, I.; Flogel, O.; Lelais, G.; Togni, A.; Seebach, D., Electrophilic S-Trifluoromethylation of Cysteine Side Chains in alpha- and beta-Peptides: Isolation of Trifluoronethylated Sandostatin (R) (Octreotide) Derivatives. Helv Chim Acta 2008, 91 (11), 2035-2056.

45. Vaclavik, J.; Zschoche, R.; Klimankova, I.; Matousek, V.; Beier, P.; Hilvert, D.; Togni, A., Irreversible Cysteine-Selective Protein Labeling Employing Modular Electrophilic Tetrafluoroethylation Reagents. Chemistry 2017, 23 (27), 6490-6494.

46. $\quad$ Charkoudian, L. K.; Liu, C. W.; Capone, S.; Kapur, S.; Cane, D. E.; Togni, A.; Seebach, D.; Khosla, C., Probing the interactions of an acyl carrier protein domain from the 6-deoxyerythronolide B synthase. Protein Sci 2011, 20 (7), $1244-1255$.

47. Li, Y.; Studer, A., Transition-Metal-Free Trifluoromethylaminoxylation of Alkenes. Angew Chem Int Edit 2012, 51 (33), $8221-$ 8224.

48. Lin, Q. Y.; Xu, X. H.; Qing, F. L., Chemo-, Regio-, and Stereoselective Trifluoromethylation of Styrenes via Visible LightDriven Single-Electron Transfer (SET) and Triplet-Triplet Energy Transfer (TTET) Processes. J Org Chem 2014, 79 (21), 1043410446.

49. Budinska, A.; Vaclavik, J.; Matousek, V.; Beier, P., Nucleophilic Tetrafluoroethylation Employing in Situ Formed Organomagnesium Reagents. Org Lett 2016, 18 (22), 5844-5847.

50. $\quad$ Eng, J. K.; Mccormack, A. L.; Yates, J. R., An Approach to Correlate Tandem Mass-Spectral Data of Peptides with AminoAcid-Sequences in a Protein Database. J Am Soc Mass Spectr 1994, 5 (11), 976-989.

51. Yan, T. Y.; Desai, H. S.; Boatner, L. M.; Yen, S. L.; Cao, J.; Palafox, M. F.; Jami-Alahmadi, Y.; Backus, K. M., SP3-FAIMS Chemoproteomics for High-Coverage Profiling of the Human Cysteinome**. Chembiochem 2021, 22 (10), 1841-1851.

52. $\quad$ Eden, E.; Navon, R.; Steinfeld, I.; Lipson, D.; Yakhini, Z., GOrilla: a tool for discovery and visualization of enriched GO terms in ranked gene lists. Bmc Bioinformatics 2009, 10.

53. Eden, E.; Lipson, D.; Yogev, S.; Yakhini, Z., Discovering motifs in ranked lists of DNA sequences. Plos Comput Biol 2007, 3 (3), 508-522.

54. Lagoutte, R.; Serba, C.; Abegg, D.; Hoch, D. G.; Adibekian, A.; Winssinger, N., Divergent synthesis and identification of the cellular targets of deoxyelephantopins. Nature Communications 2016, 7.

55. Tomanik, M.; Economou, C.; Frischling, M. C.; Xue, M. Z.; Marks, V. A.; Mercado, B. Q.; Herzon, S. B., Development of a Convergent Enantioselective Synthetic Route to (-)-Myrocin G. J Org Chem 2020, 85 (14), 8952-8989.

56. Pommier, Y.; Leo, E.; Zhang, H. L.; Marchand, C., DNA Topoisomerases and Their Poisoning by Anticancer and Antibacterial Drugs. Chem Biol 2010, 17 (5), 421-433.

57. da Costa, T. P. S.; Tieu, W.; Yap, M. Y.; Zvarec, O.; Bell, J. M.; Turnidge, J. D.; Wallace, J. C.; Booker, G. W.; Wilce, M. C. J.; Abell, A. D.; Polyak, S. W., Biotin Analogues with Antibacterial Activity Are Potent Inhibitors of Biotin Protein Ligase. Acs Med Chem Lett 2012, 3 (6), 509-514.

58. Jin, S. F.; Inoue, S.; Weaver, D. T., Differential etoposide sensitivity of cells deficient in the Ku and DNA-PKcs components of the DNA-dependent protein kinase. Carcinogenesis 1998, 19 (6), 965-971. 
59. Fell, V. L.; Schild-Poulter, C., Ku Regulates Signaling to DNA Damage Response Pathways through the Ku70 von Willebrand A Domain. Mol Cell Biol 2012, 32 (1), 76-87.

60. Wang, Y. J.; Dix, M. M.; Bianco, G.; Remsberg, J. R.; Lee, H. Y.; Kalocsay, M.; Gygi, S. P.; Forli, S.; Vite, G.; Lawrence, R. M.; Parker, C. G.; Cravatt, B. F., Expedited mapping of the ligandable proteome using fully functionalized enantiomeric probe pairs. Nat Chem 2019, 11 (12), 1113-1123.

61. Chumoyer, M. Y.; Danishefsky, S. J., On the Mode of Action of Myrocin-C - Evidence for a Cc-1065 Connection. Tetrahedron Lett 1993, 34 (19), 3025-3028.

62. Walker, J. R.; Corpina, R. A.; Goldberg, J., Structure of the Ku heterodimer bound to DNA and its implications for doublestrand break repair. Nature 2001, 412 (6847), 607-614.

63. Mah, L. J.; El-Osta, A.; Karagiannis, T. C., gamma H2AX: a sensitive molecular marker of DNA damage and repair. Leukemia 2010, 24 (4), 679-686.

64. $\quad$ An, J.; Huang, Y. C.; Xu, Q. Z.; Zhou, L. J.; Shang, Z. F.; Huang, B.; Wang, Y.; Liu, X. D.; Wu, D. C.; Zhou, P. K., DNA$\mathrm{PKcs}$ plays a dominant role in the regulation of $\mathrm{H} 2 \mathrm{AX}$ phosphorylation in response to DNA damage and cell cycle progression. $B M C$ Mol Biol 2010, 11, 18

65. Mohiuddin, I. S.; Kang, M. H., DNA-PK as an Emerging Therapeutic Target in Cancer. Front Oncol $2019,9$.

66. Wirthner, R.; Wrann, S.; Balamurugan, K.; Wenger, R. H.; Stiehl, D. P., Impaired DNA double-strand break repair contributes to chemoresistance in HIF-1 alpha-deficient mouse embryonic fibroblasts. Carcinogenesis 2008, 29 (12), $2306-16$.

67. Zhao, H.; Rybak, P.; Dobrucki, J.; Traganos, F.; Darzynkiewicz, Z., Relationship of DNA damage signaling to DNA replication following treatment with DNA topoisomerase inhibitors camptothecin/topotecan, mitoxantrone, or etoposide. Cytom Part $A$ 2012, 81a (1), 45-51.

68. Pannunzio, N. R.; Watanabe, G.; Lieber, M. R., Nonhomologous DNA end-joining for repair of DNA double-strand breaks. Journal of Biological Chemistry 2018, 293 (27), 10512-10523.

69. $\quad$ Chang, I. Y.; Youn, C. K.; Kim, H. B.; Kim, M. H.; Cho, H. J.; Yoon, Y.; Lee, Y. S.; Chung, M. H.; You, H. J., Oncogenic HRas up-regulates expression of Ku80 to protect cells from gamma-ray irradiation in NIH3T3 cells. Cancer Res 2005, 65 (15), 6811 6819.

70. $\quad$ Chang, H. W.; Kim, S. Y.; Yi, S. L.; Son, S. H.; Song, D. Y.; Moon, S. Y.; Kim, J. H.; Choi, E. K.; Do Ahn, S.; Shin, S. S.; Lee, K. K.; Lee, S. W., Expression of Ku80 correlates with sensitivities to radiation in cancer cell lines of the head and neck. Oral Oncol 2006, 42 (10), 979-986.

71. $\quad$ Ma, Q. S.; Li, P.; Xu, M. Y.; Yin, J. Z.; Su, Z. Z.; Li, W.; Zhang, J., Ku80 is highly expressed in lung adenocarcinoma and promotes cisplatin resistance. J Exp Clin Canc Res 2012, 31.

72. Shang, B.; Jia, Y.; Chen, G.; Wang, Z., Ku80 correlates with neoadjuvant chemotherapy resistance in human lung adenocarcinoma, but reduces cisplatin/ pemetrexed-induced apoptosis in A549 cells. Resp Res 2017, 18.

73. Zhuang, L.; Liu, F.; Peng, P.; Xiong, H. H.; Qiu, H.; Fu, X. G.; Xia, Z. P.; Huang, X. Y., Effect of Ku80 on the radiosensitization of cisplatin in the cervical carcinoma cell line HeLa. Oncol Lett 2018, 15 (1), 147-154.

74. Hsieh, M. J.; Huang, C.; Lin, C. C.; Tang, C. H.; Lin, C. Y.; Lee, I. N.; Huang, H. C.; Chen, J. C., Basic fibroblast growth factor promotes doxorubicin resistance in chondrosarcoma cells by affecting XRCC5 expression. Mol Carcinogen 2020, 59 (3), 293303.

75. $\quad$ Fan, Y. L.; Li, J. Y.; Wei, W.; Fang, H. R.; Duan, Y.; Li, N. M.; Zhang, Y. Y.; Yu, J.; Wang, J. H., Ku80 gene knockdown by the CRISPR/Cas9 technique affects the biological functions of human thyroid carcinoma cells. Oncol Rep 2019, 42 (6), $2486-2498$.

76. Lee, I. N.; Yang, J. T.; Huang, C.; Huang, H. C.; Wu, Y. P.; Chen, J. C., Elevated XRCC5 expression level can promote temozolomide resistance and predict poor prognosis in glioblastoma. Oncol Lett 2021, 21 (6).

77. Gu, Z. Y.; Li, Y. X.; Yang, X. Y.; Yu, M. S.; Chen, Z. R.; Zhao, C.; Chen, L. X.; Wang, L. W., Overexpression of CLC-3 is regulated by XRCC5 and is a poor prognostic biomarker for gastric cancer. J Hematol Oncol 2018, 11.

78. $\quad$ Zhang, Z. F.; Zheng, F. F.; Yu, Z. L.; Hao, J. J.; Chen, M.; Yu, W. D.; Guo, W.; Chen, Y. M.; Huang, W. L.; Duan, Z. J.; Deng, W. G., XRCC5 cooperates with p300 to promote cyclooxygenase-2 expression and tumor growth in colon cancers. Plos One 2017, $12(10)$.

79. $\quad$ Tonotsuka, N.; Hosoi, Y.; Miyazaki, S.; Miyata, G.; Sugawara, K.; Mori, T.; Ouchi, N.; Satomi, S.; Matsumoto, Y.; Nakagawa, K.; Miyagawa, K.; Ono, T., Heterogeneous expression of DNA-dependent protein kinase in esophageal cancer and normal epithelium. Int J Mol Med 2006, 18 (3), 441-447.

80. Kim, D. S.; Camacho, C. V.; Kraus, W. L., Alternate therapeutic pathways for PARP inhibitors and potential mechanisms of resistance. Exp Mol Med 2021, 53 (1), 42-51. 